\title{
Self-metallization of photocatalytic porphyrin nanotubes
}

Zhongchun Wang ${ }^{\dagger, \S}$ Craig J. Medforth, ${ }^{\dagger}$ and John A. Shelnutt ${ }^{\dagger, \ddagger}$

Biomolecular Materials and Interfaces Department, Sandia National Laboratories, Albuquerque, NM 87185, Department of Chemical and Nuclear Engineering, University of New Mexico, Albuquerque, NM 87131, Department of Chemistry, University of Georgia, Athens, GA 30602

\section{Supporting Information}

Synthesis of Nanotubes. The photocatalytic porphyrin nanotubes used in this work were prepared by ionic self assembly of two porphyrins, meso-tetrakis(4-phenylsulfonicacid)porphyrin $\left(\mathrm{H}_{2} \mathrm{TPPS}_{4}\right)$ dihydrochloride and $\mathrm{Sn}(\mathrm{IV})$ tetrakis(4-pyridyl)porphyrin $\left(\mathrm{SnTPyP}^{2+}\right)$ dichloride, as reported previously (Z. Wang, C. J. Medforth, and J. A. Shelnutt, J. Am. Chem. Soc. 2004, in press). Typically, $9 \mathrm{~mL}$ of $\mathrm{H}_{2} \mathrm{TPPS}_{4}{ }^{4-}$ dihydrochloride solution $\left(10.5 \mu \mathrm{M} \mathrm{H}_{2} \mathrm{TPPS}_{4}\right.$ dihydrochloride in $0.02 \mathrm{M} \mathrm{HCl}$ ) was mixed with $9 \mathrm{~mL}$ of $\operatorname{SnTPyP}^{2+}$ solution $\left(3.5 \mu \mathrm{M} \mathrm{SnTPyP}^{2+}\right.$ dichloride in water) and the mixture left in the dark and undisturbed at room temperature for approximately 72 hours. Both porphyrins were purchased from Frontier Scientific and used without further purification. Hydrochloric acid solution $(1.0 \mathrm{M})$ was purchased from VWR. All the solutions used in the synthesis were prepared using ultrapure water from a Barnstead Nanopure water system and were filtered through $0.2-\mu \mathrm{m}$ syringe filters to remove particles. The porphyrin stock solutions were stored in the dark and used within a week.

Porphyrin-nanotube Catalyzed Photoreduction of Gold and Platinum. Potassium tetrachloroplatinate(II) $\left(\mathrm{K}_{2} \mathrm{PtCl}_{4} ; 99.99 \%\right)$, hydrogen tetrachloroaurate(III) ( $\mathrm{HAuCl}_{4} ; 17$ wt.\% solution in dilute hydrochloric acid; 99.99\%), L-ascorbic acid (99+\%), and thiourea (99+\%) were purchased from Aldrich and used without further purification. All solutions were prepared using ultrapure water. Ascorbic acid is unstable in water, so stock solutions (0.2 M) were freshly prepared before each reaction. $\mathrm{K}_{2} \mathrm{PtCl}_{4}$ solution $(20 \mathrm{mM})$ was prepared and equilibrated overnight (Ciacchi, L. C.; Pompe, W.; De Vita, A. J. Am. Chem. Soc. 2001, 123, 7371). The gold solutions for the photocatalytic deposition of gold were freshly prepared by reducing $\mathrm{Au}$ (III) to Au(I) with thiourea (V. Gaspar, A. S. Mejerovich, M. A. Meretukov, and J. Schmiedl, Hydrometallurgy, 1994, 34, 369). Typically, $17 \mathrm{mg}$ of thiourea powder was slowly added to $1 \mathrm{ml}$ of $\mathrm{HAuCl}_{4}$ solution $(20 \mathrm{mM})$ and the mixture agitated to dissolve the thiourea. After a few minutes, the yellow $\mathrm{Au}(\mathrm{III})$ solution turned into a transparent and colorless solution of $\mathrm{Au}(\mathrm{I})(\text { thiourea })_{\mathrm{x}}$ complex.

(1) Gold Deposition Reactions: For the gold photoreduction experiments, $50 \mu$ of $\mathrm{Au}(\mathrm{I})$ (thiourea) $)_{\mathrm{x}}$ solution $(20 \mathrm{mM} \mathrm{Au})$ and $50 \mu \mathrm{l}$ of ascorbic acid solution $(0.2 \mathrm{M})$ were added to a 2-ml glass vial containing $1 \mathrm{ml}$ of the nanotube colloidal suspension $\left(\mathrm{SnTPyP}^{2+}\right.$ concentration $1.75 \mu \mathrm{M})$. The reaction mixture was swirled to homogenize the solution, placed in a glass water bath to control the temperature, and then irradiated with incandescent light (800 nmol cm $\mathrm{nm}^{-1}$ ) for 8 minutes. The light intensity was measured with a Hansatech Instruments (Norfolk, England) 
Quantitherm light meter. No gold deposition was observed in control experiments without light exposure or in the absence of the porphyrin nanotubes.

(2) Platinum Deposition Reactions: For the Pt photoreduction experiments, $\mathrm{K}_{2} \mathrm{PtCl}_{4}$ stock solution (20 mM Pt) and ascorbic acid stock solution $(0.2 \mathrm{M})$ were added to a 2-ml glass vial containing $1 \mathrm{ml}$ of the nanotube colloidal suspension $\left(\mathrm{SnTPyP}^{2+}\right.$ concentration $\left.1.75 \mu \mathrm{M}\right)$. The reaction mixture was swirled to homogenize the solution, placed in a glass water bath to control the temperature, and then irradiated with incandescent light $\left(800 \mathrm{nmol} \mathrm{cm}^{-2} \mathrm{~s}^{-1}\right)$. When a low concentration of platinum salt $(0.1 \mathrm{mM})$ was used in the reaction, $5 \mu \mathrm{l}$ of $\mathrm{K}_{2} \mathrm{PtCl}_{4}$ stock solution and $5 \mu \mathrm{l}$ of ascorbic acid stock solution were added and the light exposure time was 15 min. When a high concentration of platinum salt $(1 \mathrm{mM})$ was employed in the reaction, $50 \mu \mathrm{l}$ of $\mathrm{K}_{2} \mathrm{PtCl}_{4}$ stock solution and $50 \mu \mathrm{l}$ of ascorbic acid stock solution were added and the light exposure time was 15 or $35 \mathrm{~min}$. The porphyrin concentration was essentially the same for all the reactions $\left(1.75 \mu \mathrm{M} \operatorname{SnTPyP}^{2+}\right)$.

Hydrogen Evolution Measurements. All the hydrogen evolution reactions were run under an argon atmosphere using a reaction vessel consisting of a round-bottom Pyrex tube (4 in. in height and 0.5 in. in diameter) sealed with a rubber septum. To this vessel were added $2.5 \mathrm{ml}$ of a suspension of the platinized porphyrin nanotubes $\left(\mathrm{SnTPyP}^{2+}\right.$ concentration $\left.17.5 \mu \mathrm{M}\right)$ and $31 \mathrm{mg}$ of ascorbic acid (producing a final ascorbic acid concentration of $70 \mathrm{mM}$ ). The TEM images of the platinized porphyrin nanotubes used in the reaction were similar to those shown in Figure 2a. The reaction vessel was irradiated with a tungsten light source $\left(800 \mathrm{nmol} \mathrm{cm}{ }^{-2}-\mathrm{s}^{-1}\right.$ at the outer wall of the vessel) while the suspension was gently agitated with a magnetic stirrer. Samples were periodically taken from the head-space of the reaction vessel with a gas-tight syringe for analysis by gas chromatography (HP 5890 Series II).

Characterizations. Transmission electron microscopy and energy-dispersive X-ray spectroscopy were performed on a JEOL 2010 transmission microscope (200 keV). The samples for TEM analysis were prepared by pipetting 5-25 $\mu \mathrm{l}$ of the colloidal suspensions onto standard holey carbon-coated copper grids. The excess solvent was wicked away by a Kimwipe ${ }^{\circledR}$ tissue underneath the copper grid. The grids were air dried for at least 2 hours before being loaded into the vacuum chamber of the electron microscope. The TEM samples were not subject to heavymetal staining or other treatments. 